\title{
EARLY HOLOCENE BURIAL PRACTICE AT NIAH CAVE, SARAWAK
}

\author{
Lindsay Lloyd-Smith \\ Institute for East Asian Studies, Sogang University, Seoul, South Korea. \\ Email: 1loyd-smith@,cantab.net \\ Keywords: Early Holocene, Burial Practice, Niah Cave, Borneo
}

\begin{abstract}
The West Mouth of Niah Cave, Sarawak, contains one of the largest series of stratified prehistoric burials in Southeast Asia. Initial classification grouped up to 39 burials as 'Mesolithic' or pre-Neolithic (B. Harrisson 1967), including 'flexed', 'seated' and 'mutilation' burials, and subsequent radiocarbon dates on human bone produced a date range for these burials of 15,121-5659 cal. BC (Brooks et al. 1977; T. Harrisson 1975). However, due to the technical infancy in dating bone samples at that time, these dates are now generally discredited (Spriggs 1989). In light of renewed investigation of cave stratigraphy and new radiocarbon dates, this paper reviews the classification and date range of early Holocene burials at Niah Cave. The spatial and temporal patterning in burial practice at the site is discussed and compared to the regional data. It is proposed that the commencement of discrete burial in the early Holocene forms a horizon across the Indo-Malay Archipelago which reflects a broad cultural shift in the perception of dead and cultural attitudes to their appropriate treatment, one result of which was the creation of tangible ancestral identities. Early Holocene burial practice was varied both at a local and regional level, including primary as well as secondary burial. One widespread element is the use of fire, either represented as fully cremated remains or physically present within the grave structure itself.
\end{abstract}

\section{INTRODUCTION}

Discrete human burials are a common feature at archaeological sites in Southeast Asia where there is evidence for occupation dating to the early Holocene (Anderson 1997), and they are found across the region (Figure 1). Secure and reliable absolute dating of such burials has been problematic, particularly where complicated site stratigraphy or excavation/recording methods meant that grave cuts and burial features were not recognised in the field. Nevertheless, the deeply stratified locations of these burials and absence of later material culture (ceramics, metals, glass beads, etc) are generally taken to propose a broad early Holocene, or pre-Neolithic, date (10,000-2000 BC).

Even though burial is one of the most ritually elaborated and symbolically laden characteristics of human society, early Holocene mortuary practice of Southeast Asia and the contribution the data can make to debates concerning the nature and structure of these societies, possible regional spheres of interaction, and population histories (Bulbeck 2008; O'Connor 2006; Soares et al. 2008) has been overlooked. A concern of such studies is whether, and to what degree, early Holocene communities of island Southeast Asia contributed to the later social and economic transformations of the Neolithic. However, one of the major hindrances in exploring this issue is the coarseness of early Holocene site chronologies (Spriggs 2011), not least as noted above in the dating of burials. Subsequently, there is lack of understanding of how early Holocene archaeological sites and assemblages are the result of histories of local tradition which shaped, and were shaped by the lives, and importantly the deaths, of individual people.

A death of an individual represents a social crisis for a community and the treatment and disposal of the dead are arenas in which relationships between living (particularly those performing the burial), as well as relationships between the ancestors and the community are played out, reconfigured and re-negotiated (Bloch and Parry 1982; Huntington and Metcalf 1979). Repeated funerary rituals leading to the creation of a collection of archaeologically detectable burial features offer a window on the past that is neither a snap-shot of a single event neither a conflation of material over several millennia. Rather, the spatial and temporal arrangement and structure of early Holocene burial features represent physical manifestations of histories of cultural tradition.

One of the largest and best preserved early Holocene burial populations in Island Southeast Asia is found in the West Mouth, Niah Cave (Sarawak), and as such the site has the potential to provide a base line from which to discuss the burial data from across the region. A prerequisite of approaching early Holocene sites as fundamentally 'historically' created is a robust and reliable classification system and accurate data on the date, distribution and arrangement of burials. In the following paper, after a brief introduction to the early Holocene environmental and archaeological context of the site, the original burial classification (B. Harrisson 1967) is critically examined. An amended reclassification is proposed and spatial/temporal patterning in early Holocene burial types analysed as a basis for examining the construction of 


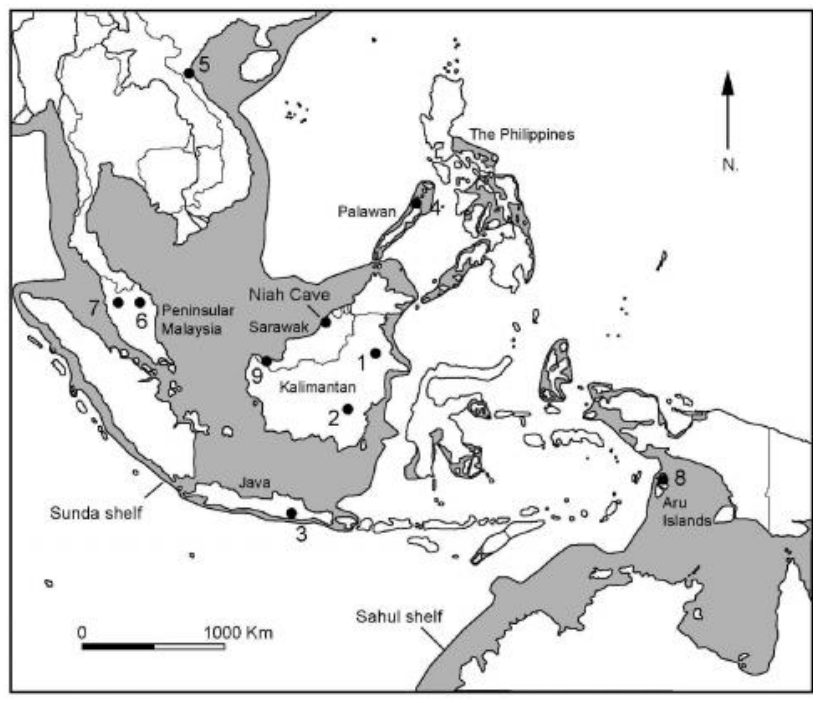

Figure 1. Southeast Asia, showing the principal regions and sites mentioned in the paper. (1. Kimanis; 2. Gua Tengkorak; 3. Gunung Sewu sites Song Terrus, Song Keplek, and Gua Braholo; 4. Ille Cave; 5. Da But cultural sites; 6. Gua Cha and Gua Peraling; 7. Gua Teluk Ke-lawar; 8. Liang Lemdubu; 9. Gua Sireh)

traditions of ritual practice at a local level. This analysis foregrounds sites of burial as places of history, comprising a web of social relationships and identities. The spatial and temporal dimensions of the final funerary rituals that took place during the early Holocene at Niah are analysed to propose how selective and differential treatment of dead within these traditions fed into concepts of individual, group, and ancestral identities. In the final section, the burial evidence from the Niah is placed in the regional context and the implications for broader patterns in shared ritual practice are discussed.

All radiocarbon dates and date ranges discussed in this paper have been calibrated to 2 sigma, using the online OxCal 4.10 program with the IntCal 09 calibration curve.

\section{EARLY HOLOCENE ENVIRONMENT AND ARCHAEOLOGY OF THE NIAH CAVES}

The Niah Caves are located about fifteen kilometres from the north Borneo coast. Excavations at numerous sites by Tom and Barbara Harrisson in the 1950s and 1960s exposed a long sequence of Pleistocene and Holocene occupation and burial dated from around 40,000 years ago to the present day (B. Harrisson 1967; T. Harrisson 1970. The largest and most intensively studied of these sites is the West Mouth: over $160 \mathrm{~m}$ wide and $60 \mathrm{~m}$ high at its entrance (Figure 2). The Harrissons excavated over 30 deeply stratified human burials below 24 " (=0.60 m), and above this level over 200 Neolithic burials. Renewed fieldwork by the Niah Caves Project (2000-2004), include ing a programme of re-dating and archival study, has been able to reconstruct the stratigraphy and occupation history of the West Mouth by studying remaining section baulks

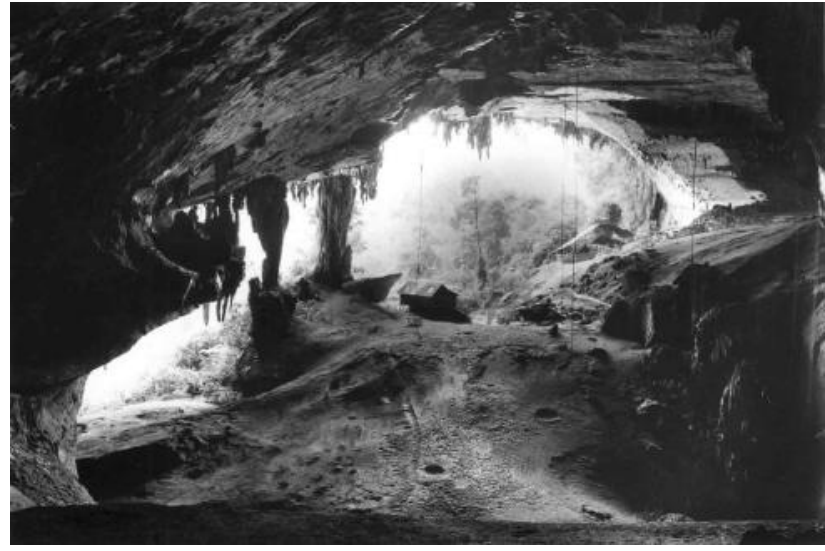

Figure 2. The West Mouth of Niah Cave. The main archaeological zone is on the far right. (Photograph: G. Barker)

and exposed sections augmented by targeted excavations (Barker et al. 2013). Taking the presence of charcoal as a proxy for human activity in the cave, the new dates suggest that the early Holocene use of the West Mouth (c.10,000-6000 BC) was followed by a gap of some 4000 years (Krigbaum 2001). The Neolithic cemetery dates to c. 1500 to 200 BC (Lloyd-Smith 2013)

In terms of the environment, increasing global temperatures during the early Holocene resulted in rising sea levels and the inundation of the Sunda Shelf culminating in a mid-Holocene high-sea stand. Cores taken outside the cave have marine clays at their base, corresponding to the period during which the Niah Caves were located on an off-shore island or coastal headland (Hunt and Rushworth 2005). The on-set of these conditions at Niah has been not dated, but is presumably not earlier than the date of c.6000 BC from inside the West Mouth. Radiocarbon dates at the top the basal clays indicate that the coast was receding by c. $4000 \mathrm{BC}$.

Stratified deposits in the West Mouth dating to the early Holocene contain a range of hunted fauna indicative of a high-canopy rainforest environment including bearded pig, primates, and occasional large browsing ungulates such as cattle, tapir, and deer (Barker et al. 2009). The remains of Asian softshell turtle and molluscs from brackish water environments also indicate the exploitation of riverine/estuarine resources. Plant remains include a range of edible plants (yams, taro, and sedges) probably used for food, and non-edible plants such as vines, probably used for baskets, etc (Barton and Paz 2007). Early Holocene lithic technologies at Niah continued the use of basic core and flake reduction strategies, but also saw the increase of mortars, pestles, and other ground stone artefacts (Zuraina Majid 1986).

Isotopic studies indicate that the majority of the deeply stratified burials have signatures indicative of a closecanopy diet (Krigbaum 2002), an interpretation that correlates well with the faunal and botanical data. Recent analysis of the face shape, cranial and dental non-metric traits in the West Mouth burials indicate that the early Holocene population at Niah were most similar to populations in the region today characterized as southern Mongoloid 


\begin{tabular}{|c|c|c|}
\hline $\begin{array}{l}\text { Burial } \\
\text { Type }\end{array}$ & Description & Phase \\
\hline Flexed & Primary burials with arms and legs bent, with ankles often under pelvis. & Pre-Neolithic \\
\hline Seated & $\begin{array}{l}\text { Primary burials with legs crossed, torso collapsed forward over pelvis as if deposited in } \\
\text { sitting position. }\end{array}$ & Pre-Neolithic \\
\hline Mutilations & $\begin{array}{l}\text { 'Mutilation that has taken place prior to decomposition of flesh and ligaments surround- } \\
\text { ing the bones, preserving articulation - for instance as parts of spinal columns, extremi- } \\
\text { ties and other body parts involving joints or small bones in perfect alignment in situ.' (B. } \\
\text { Harrisson 1967: 140). }\end{array}$ & Pre-Neolithic \\
\hline Extended & $\begin{array}{l}\text { Primary burials, usually in supine position, laid in wooden log and plank coffins, bam- } \\
\text { boo biers, and some with leaf or wooden pillows. }\end{array}$ & Neolithic \\
\hline Multiple & Discrete multiple burials of several types within single coffin. & Neolithic \\
\hline Cremation & Fully cremated secondary burials in wooden caskets, baskets and ceramic jars. & Neolithic \\
\hline Burnt & $\begin{array}{l}\text { Partially burnt secondary burials contained in wooden caskets, baskets and ceramic } \\
\text { jars. }\end{array}$ & Neolithic \\
\hline
\end{tabular}

Table 1. Barbara Harrisson's classification of burial types in the West Mouth of Niah Cave.

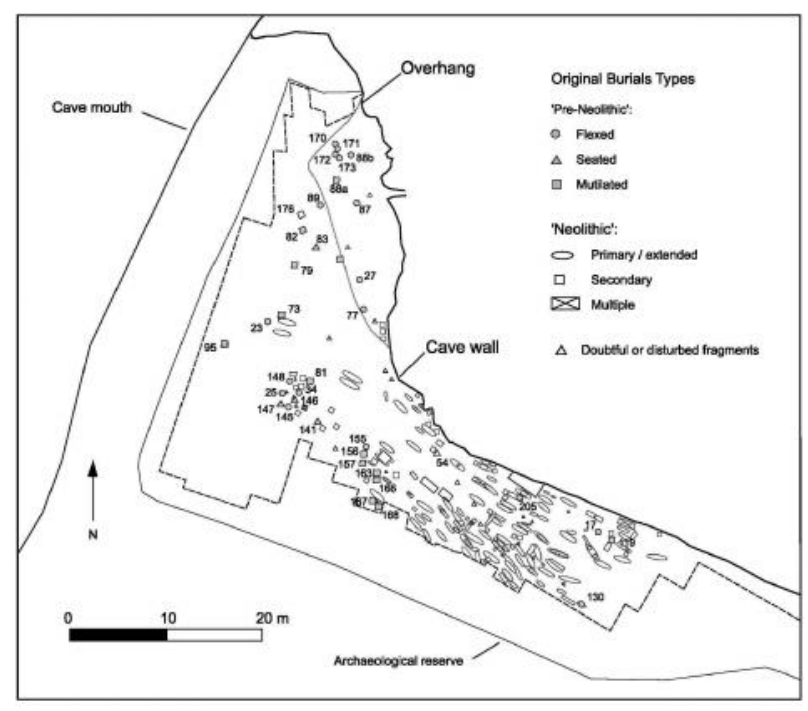

Figure 3. The West Mouth of Niah Cave: plan of the archaeological zone, showing the positions of the burials discussed in the text.

in morphology, although also demonstrating similarities to Australian and Melanesian populations (Manser 2005).

\section{EARLY HOLOCENE BURIALS AT NIAH CAVE}

The original classification employed several variable criteria, most important being the 'main physical outlines' of the burial features (Table 1; B. Harrisson 1967: 132). If doubt existed as to the nature or integrity of the deposit, they were listed as 'disturbed or doubtful fragments' (B. Harrisson 1967: 129). Seven burial types were defined in '... accordance with the varying procedures in which human skeletal remains were finally deposited on the site' (B. Harrisson 1967: 133). These were: flexed, seated, mutilations, extended, multiple, cremation and burnt. Burials were assigned to 'pre-Neolithic' (flexed, seated, and mutilated burials) or 'Neolithic' periods (extended, multiple, burnt, and cremated) based on burial type and/or their depth. However, the compaction of shallow cave deposits in some areas of the cave was noted to complicate any neat phasing of all burials (B. Harrisson 1967: 131). This was particularly the case for 'mutilation' burials. Extended, multiple, cremation and burnt burials were all assigned to the Neolithic period, however, even here there are anomalies. These anomalies undermine the usefulness of original system and a comprehensive reclassification was required prior to analysis.

Classificatory systems are not created in an objective vacuum. Typologies are created, whether explicitly or implicitly, with specific purposes in mind. The questions that are posed determine the criteria used for collecting the data. The aim of the total analysis of the Niah burials was to investigate how short-term and localised changes in mortuary practice fit into longer spatial and temporal patterns in the evolution of ritual practice and social groups (Lloyd-Smith 2009). To this end, the classificatory 


\begin{tabular}{|c|c|c|c|}
\hline $\begin{array}{l}\text { First order } \\
\text { classification }\end{array}$ & $\begin{array}{l}\text { Second order } \\
\text { Classification }\end{array}$ & $\begin{array}{l}\text { Third order } \\
\text { classification }\end{array}$ & Higher order variables \\
\hline Primary & Flexed & $\begin{array}{l}\text { Tightly flexed } \\
\text { Loosely flexed } \\
\text { 'Decapitated' }\end{array}$ & $\begin{array}{l}\text { Grave-goods } \\
\text { Red colouration }\end{array}$ \\
\hline Primary & Seated & Charred & - \\
\hline Primary & Extended & Arm positioning & $\begin{array}{l}\text { Container: coffin, bamboo, } \\
\text { Grave-goods } \\
\text { Red coloration }\end{array}$ \\
\hline Secondary & $\begin{array}{l}\text { Un-burnt } \\
\text { Including cremation } \\
\text { Solely cremation } \\
\text { Semi-articulated remains }\end{array}$ & Skull only & $\begin{array}{l}\text { Container: coffin, bamboo, sherd- } \\
\text { cover, burial jar } \\
\text { Grave-goods } \\
\text { Red coloration }\end{array}$ \\
\hline Multiple & Including cremation & - & Container: coffin, bamboo \\
\hline
\end{tabular}

Table 2. Orders of re-classification of burials at Niah Cave.

criteria employed were the appearance and characteristics of burials contexts; the treatment and arrangement of the body; the physical contents (bones, containers, artefacts) of burial deposits; and the spatial and temporal location of burials

In reassessing the Niah data, the term 'burial' is taken to mean the deliberate deposition of human remains. A hierarchical classification system was employed so as all burials could be progressively grouped by first, second, and third order criteria (Table 2). Ultimately, the proposed classification of burial types, and the handling of these data, are built on two premises: first, that 'like goes with like'; and second, that the criteria used to group the data were also recognised by the people who created the burial contexts in the past. It follows from this that these behaviours created patterns of 'normal' burial. It further follows that variation from the norms can also be viewed as significant and meaningful.

The first order distinction is between 'primary' and 'secondary' burial. Primary burial refers to a single stage funeral for the disposal of the dead, in this case by interment in the ground. Secondary burial implies the transformation of the body, for example through cremation or the exhumation and manipulation of the skeletal remains, followed by a final (secondary) burial. Second order variables include the positioning of primary burials and whether secondary remains were unburnt or cremated. Higher order variables include the presence of red pigment (ochre?), and the association of material artifacts (containers for the body, grave-goods, etc). (Two oversized coffins in the Neolithic cemetery, containing primary and secondary burials, retained their original designation as 'multiple' burials.)

Each of the main burial types originally grouped as pre-Neolithic (flexed, seated and mutilations) are discussed in turn. Originally these numbered up to 39 (Figure 3). After re-classification a total of 25 burials is now proposed to date to the early Holocene. These include a secondary burial cremation (B176) originally assigned to the Neolithic. This burial is discussed alongside two 'mu- tilation' burials (B82 and B92), which are here also reclassified as secondary burials likely dating to the early Holocene. The criteria used to provisionally phase these burials are largely the same as those employed by Barbara Harrisson, namely: depth, location, and associated material culture. The spatial patterning in the burial types is then discussed along with new data on cave stratigraphy and new radiocarbon dates to propose a refined chronology for early Holocene burial at Niah. Tables of the reclassified burials discussed in this paper are in the presented after considering each burial type.

\section{Flexed burials}

Eighteen burials were originally listed as flexed: B17, B23, B25, B27, B34, B77, B84, B87, B88B, B89, B130, $\mathrm{B} 145, \mathrm{~B} 148, \mathrm{~B} 155, \mathrm{~B} 170, \mathrm{~B} 171, \mathrm{~B} 172$, and $\mathrm{B} 173$. In addition, flexed burial B205 was uncovered in the final few weeks of the excavation in the area of the Neolithic cemetery (B. Harrisson 1967: 136). Excavated in 2003, this burial was found with a polished lenticular adze, an item of material culture that typifies the Neolithic (Barker et al. 2003: 69, 94), and radiocarbon dates place B205 in the Early Neolithic phase (1500-1300 BC) of the West Mouth cemetery (Lloyd-Smith 2013: 117-119). Concerning the other 'flexed' burials (B17 and B130) in this area of the cave, on reassessment of the field data it is unclear why they were so classified. On photographic evidence B17 is reclassified as a secondary burial/unburnt, and the condition of the bones suggest it belongs with the Neolithic cemetery. The classification of B130 remains unsure; no field notes remain, but photographs do possibly show a loosely flexed inhumation burial. The same is the case for B23 in the front of the cave mouth.

The other fifteen flexed burials are well documented and their classification as flexed is supported and considered an interpretatively useful term. Flexed burials are defined as primary inhumations where the body was placed into the ground with legs and arms bent. The exact 


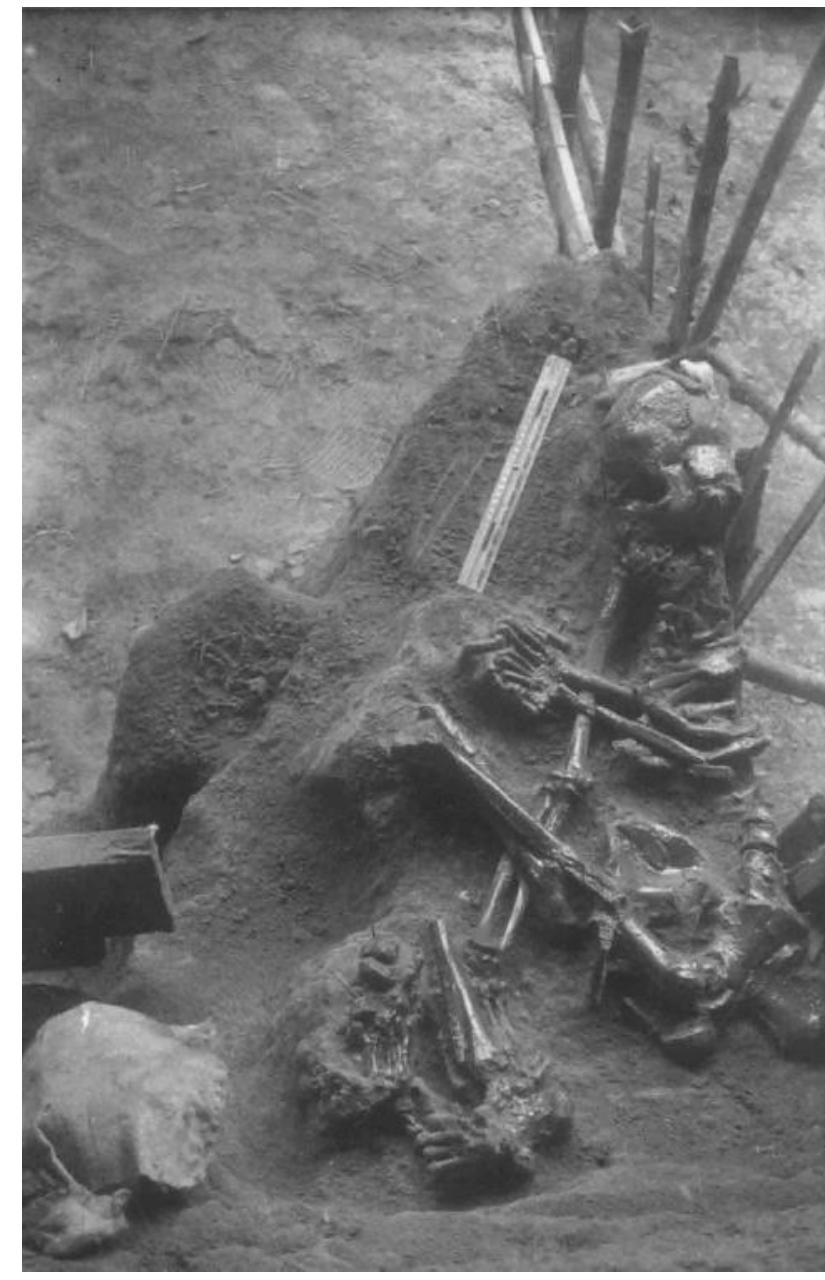

Figure 4. Flexed burial B25, an example of a tightly flexed burial, with the body laid on its right side. (Photograph courtesy of Sarawak Museum)

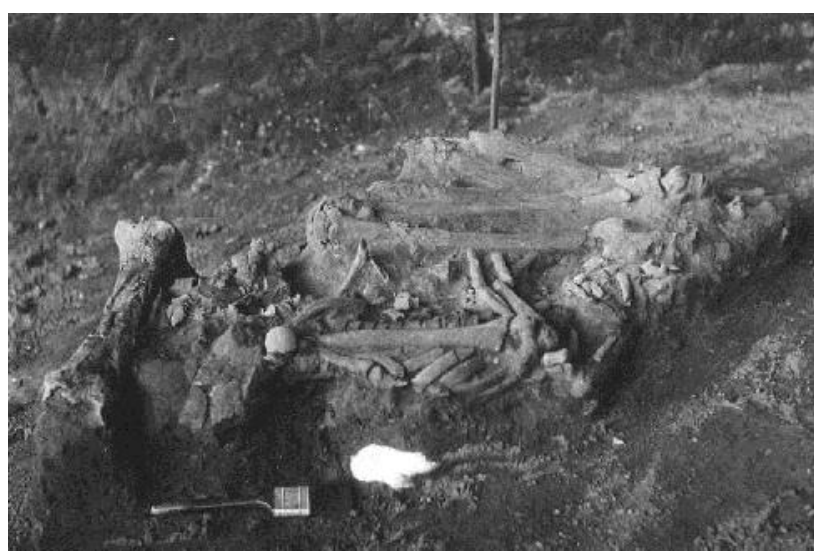

Figure 5. Flexed burial B27, with a rhinoceros leg bone placed above the head (Photograph courtesy of Sarawak Museum)

angle of the upper and lower legs (i.e. bend at hip and knee) varies, and two sub-categories of flexed burials are proposed. The majority (Burials 25, 27, 77, 84, 87, 88b, $89,145,148,155,170,171,172$, and 205) can be described as tightly flexed, where the upper legs have been brought up against the torso, and lower legs drawn up so that the feet often lie directly below the pelvis (Figures 4 and 5). These burials often have their arms also tightly bent at the elbow, with forearms bent upwards. They were placed on both their left and right sides (Burials 25, 27, $87,88 \mathrm{~b}, 89,145,155,171,172$, and 205$)$, or on their backs (Burials 84, 87, and 148). It was impossible to determine the exact position of one probably tightly flexed burial (B170). The positioning of burial B173 was also unclear from field data.

The second sub-category of flexed burials (B23, B34, and B130) is where the legs and arms are only loosely flexed. In this sense these burials differ from the more standardised positioning of the tightly flexed burials and the formalised and supine positioning of the (Neolithic) extended primary inhumations. All loosely-flexed burials were found within the upper two feet $(0.60 \mathrm{~m})$ of cave deposits, and burial B34 is part of a cluster of very shallow sub-surface burials which are thought to post-date the Neolithic cemetery (Lloyd-Smith 2013).

\section{Seated burials}

Four burials were originally classified as buried in a sitting position: B83, B141, B146 and B147. The position is described as 'comparable to the posture of later-date Buddha: legs tightly flexed to form an angular sitting platform' (B. Harrisson 1967: 139). Whilst charming, this description appears a little exaggerated and incorrect according to the field notes and photographs. The burials do not have their legs folded underneath; rather, they are splayed, with knees forward from the pelvis, as if they were resting on the edges of the grave pit. The upper body was then laid, or fell, forward between the knees and lower legs. Burials B83, B141, and B147 are most deserving of the term. The upper body of B83 lay over and between the legs, with the head resting face down on the right foot. Burial B147 was evidently placed in a narrower grave pit, with knees splayed; the upper body is described as collapsed forward. Burial B141 is not so clear as the other two, but the pelvis and femur are described in articulation, surrounded by a mass of remains. Further to these, the field data for Burial B54, originally classified as a mutilation, better describe a sitting position as well.

Perhaps what best distinguishes three of the seated burials (B54, B141, and B147) is the clear evidence of their having been placed onto a fire, lit on the base of the grave pit. The description of Burial B54 notes the '...extreme burning of bones. Indication of very hot fire. Some bone burned beyond recognition.' (B. Harrisson n.d.: B54; underlining in the original), while the lower layers of B141 are described as 'a densely compressed mass of dry bone, charred deeply. Lower mandible, deeply charred, [was] obtained from under right of centre to the far side of skull.' (B. Harrisson n.d.: B141). Burial 147 was the best preserved seated burial (Figures 6 and 7). It was noted that after 'lifting the hip bones we find that charring is heavier on the underside" (B. Harrisson n.d.:B147; underlining in the original). Also, 'there is no black on the top of the skull, but the teeth and lower jaw 


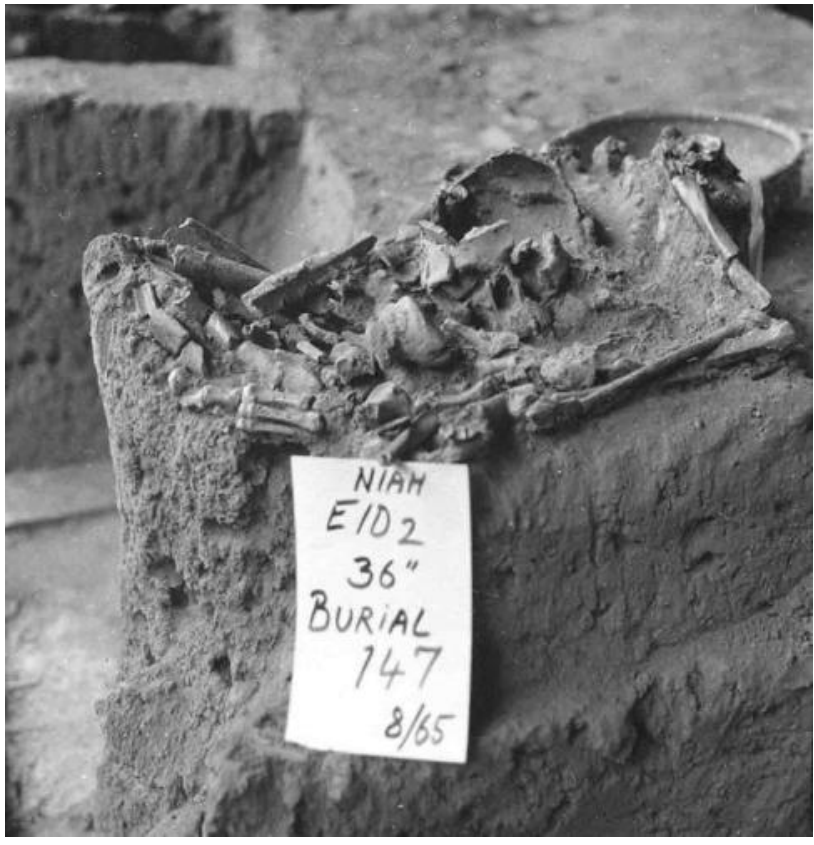

Figure 6. Early Holocene seated burial B147. (Photograph courtesy of Sarawak Museum)

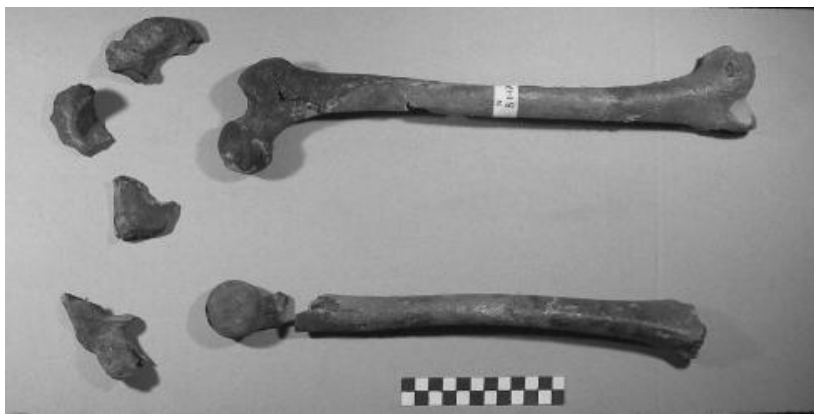

Figure 7. Fire-blackened pelvic bones and proximal ends of femurs of burial B147. Scale: $12 \mathrm{~cm}$. (Photograph: L. LloydSmith)

under [the] skull below is black. The teeth...even seem burned' (B. Harrisson n.d.:B147; underling in the original). The disturbance and breakage of some of the skeletal elements suggest that the fire was stoked after the body was placed on top of an already burning fire on the base of the grave pit, after which the graves were filled-in rather than being left open. The placing of the body into a sitting position is considered a significant part of the burial ritual that differentiates these from other flexed burials. For whatever reason (functional, symbolic or aesthetic) the sitting position was desired for those burials which were placed in a fire pit. To maintain consistency with the early classification, the term 'seated' is maintained for Burials B141, B147, and reclassified B54, with a second order of classification of 'charred'.

Burial B83 differs in that it was placed face down, with the upper body laid/fallen completely flat, between slightly raised knees. In such a position, a substantial burial pit would have been required, as opposed to a deep and narrow grave as is evident for the other seated burials.

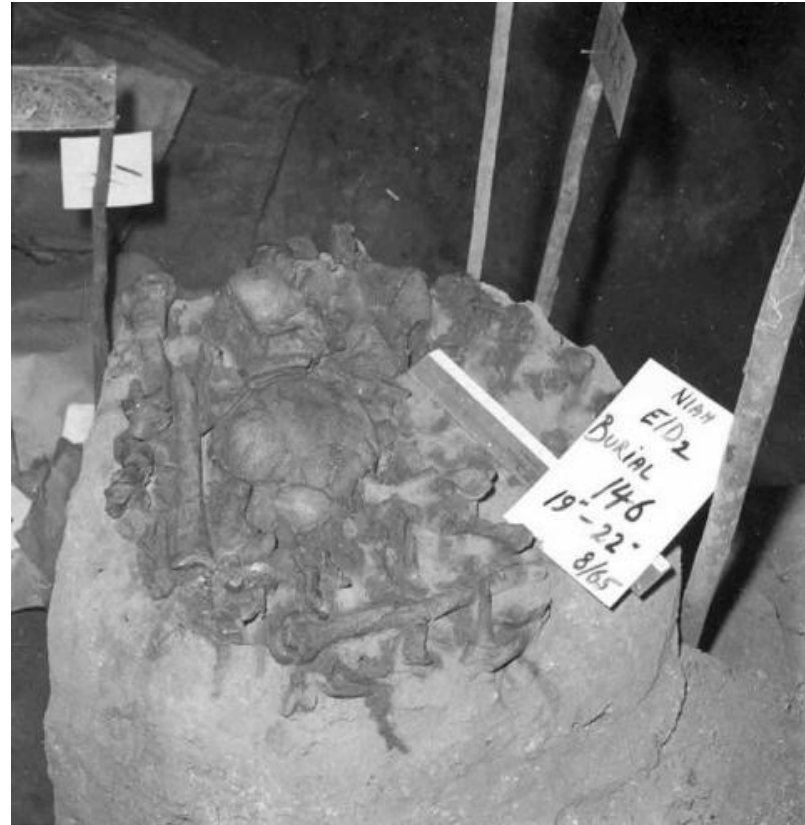

Figure 8. Burial B146 reclassified as an unburnt secondary burial, potentially dating to the Early Holocene. (Photograph courtesy of Sarawak Museum)

Importantly, there is no indication of burning of the skeleton or surrounding area. Further to this, while the three charred seated burials are all away from the overhang at the front of the cave, B83 is located midway along the edge of the overhang. B83 is thus better categorised in the order: flexed/seated, rather than seated/charred.

Burial 146 is the least recognisable as a seated burial. No mention is made of the body position, charring, or any in situ articulation. The burial is described with its 'upper jaw dislocated behind back of skull. The lower jaw is not present. Back of skull dislocated and lying over femurs, spine 'distributed' around skull, ribs and larger bones surround skull' (B. Harrisson n.d.: B146). The remains were contained enough to suggest to the excavator that they must have been buried inside something, possibly a basket. This observation was also made for the (definitely) seated burial B147, and it is perhaps this that caused B146 to be also classified originally as a seated burial. However, from the description and photographs (Figure 8 ), B146 resembles more a secondary burial, and is reclassified thus.

\section{Mutilations}

'Mutilations' are the most puzzling category of the original classification. The term appears to have been applied to a variety of burials that did not easily fit into the other burial types. Their defining characteristic was that '...mutilation has taken place prior to the decomposition of flesh and ligaments surrounding the bones, preserving articulation - for instance as parts of spinal columns, extremities and other body parts involving joints or small bones in perfect alignment, in situ.' (B. Harrisson 1967: 140 ; italics in the original). Seventeen burials were placed into four sub-categories of mutilations: 'sacrifice' (B93, 


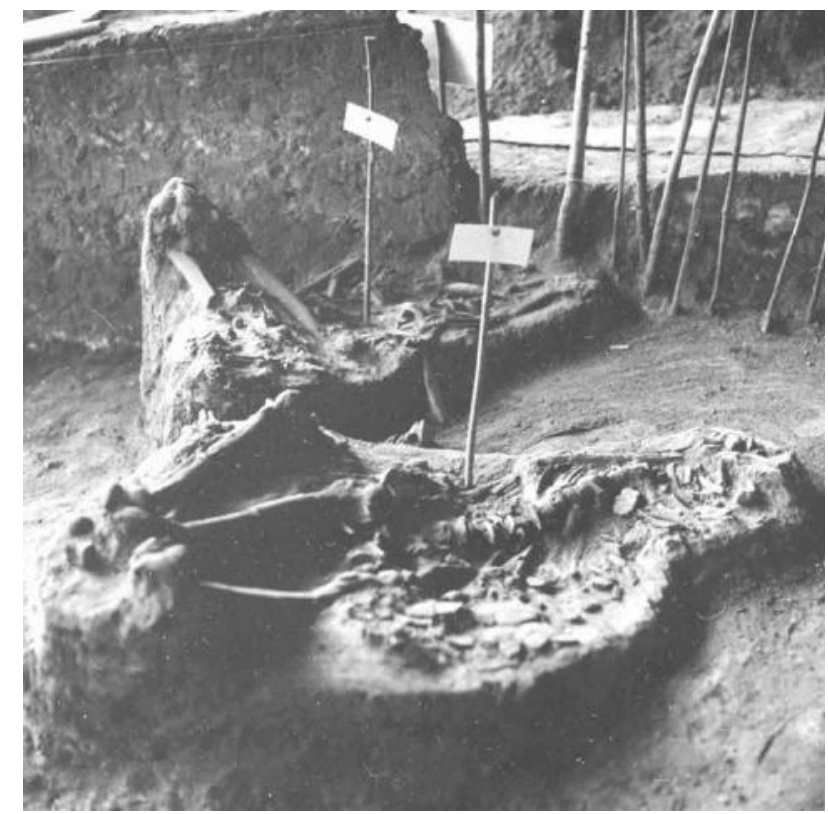

Figure 9. Early Holocene flexed decapitated burials B155 and B156. (Photograph courtesy of Sarawak Museum

B156), dismembered remains including the skull or parts thereof (B54, B73, B97, B95, B153, B157, B167/8) dismembered remains excluding the skull (B79, B88a, B92, B144, B163/6), and skulls only (B81, B82, B119) (B. Harrisson 1967: 141). Burial B119 was an isolated skull located within the Neolithic cemetery. Burial B81 was a skull located in cluster of subsurface burials towards the front of the cave, now proposed to post-date the Neolithic cemetery (Lloyd-Smith 2009). Photographs show burials B163/6 and B167/8 as only a sub-surface scattering of bones.

Burial B156 was described as a 'sacrifice' as it's 'outline...suggest[ed] the possibility of ritual murder' (B. Harrisson 1967: 141). Such an interpretation is apparently justified (Figure 9). The body was laid on its left side, with hands possibly tied behind the back, legs loosely flexed at the knee, with a skull (presumably belonging to the body) laid in front of the torso. Adjacent, was flexed burial B155, laid on its right side with its back to B156, and head on its chest with legs tightly flexed and drawn up against the torso. The position of the skull away from the vertebral column suggests that this burial was also decapitated.

Two other 'mutilations' (B88a, B93), located close to the overhang in the front of the cave and described in the field notes as in flexed positions, were also recorded without a skull. Archive photographs indicate that the upper portions of both burials were truncated by early trenches (Figure 10). The situation is still more confused by the discovery of adult cranial fragments in Sarawak Museum, labelled Burial 93. Where these fragments were discovered in relation to the burial is not known, and it cannot be definitely established that they were associated with the post-cranial material. On weight of available evidence, burials B88a, B93 and B155 are reclassified as

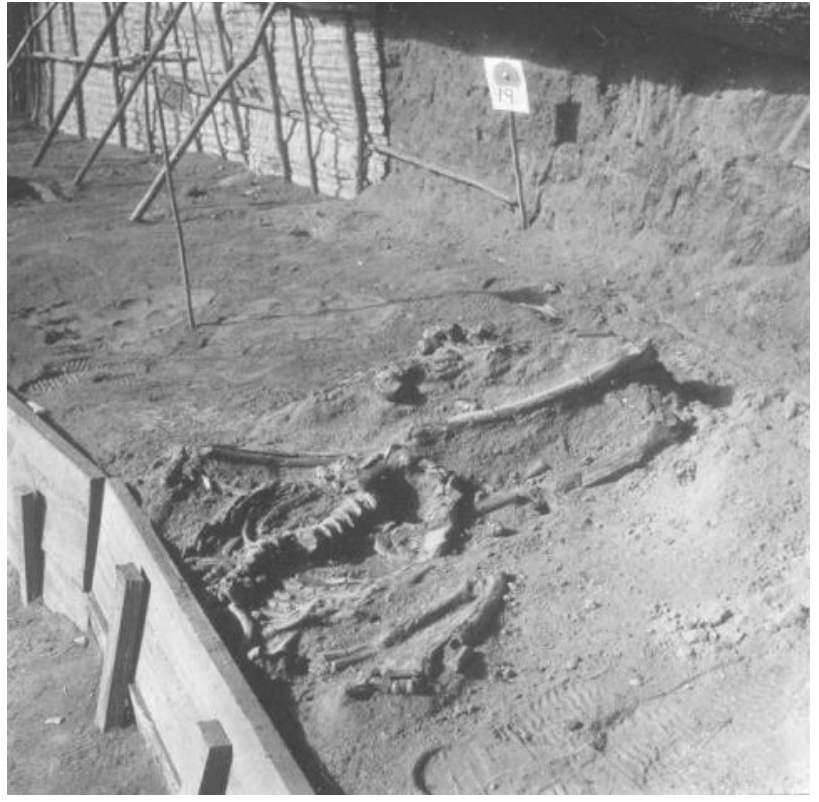

Figure 10. Flexed burial B93. Truncated above the neck by excavation in an earlier season. (Photograph courtesy of Sarawak Museum)

flexed burials/possibly decapitated. Burial number B73 was allocated to the Deep Skull. It is unclear why this was included in the sub-category of 'dismembered remains which include skulls or parts thereof' (B. Harrisson 1967: 142).

Stray human bone was also found in the vicinity of the Deep Skull (Rabett et al. 2006), but taking into consideration the new understanding of the stream-bed context of the find spot of the Deep Skull, now securely dated to c.38,000 years old (Barker et al. 2007), these remains are now categorised as a casual burial, that is to say noncontained disposal of the dead without the creation of discrete grave structures, for example the body simply left on-site and incorporated into cave's deposits by natural sedimentary processes. A similar interpretation is proposed for 'mutilation' burial B79, found at 56" (1.42 m) in the front of the cave, and comprised a single articulated left foot and assorted human bone. The depth and arrangement of the bones, and the occurrence of similar partially articulated animal remains in these deposits dating to c.15,000 years ago (Rabett et al. 2006), suggests this also represents a casual burial.

Three other mutilation burials (B82, B92 and B95) rather resemble more the typical secondary burial deposits of disarticulated human bones. Inspection of the skeletal remains revealed that one of these, B82, was cremated. This burial was found at $36 "(0.90 \mathrm{~m})$, adjacent to secondary burial cremation B176, just outside the edge of a pronounced overhang at the front of the cave under which there was a concentration of deeply stratified flexed burials. An early Holocene date for burials B82 and B92 is suggested. Burial B92 was found at the back of the same overhang, and a possible grave cut can be discerned in an archive photograph at the depth of 48 " $(1.22 \mathrm{~m})$. The only evidence for later activity in this part of the overhang is a 


\begin{tabular}{|c|c|c|c|c|c|}
\hline Burial & $\begin{array}{l}\text { Original Classification } \\
\text { (B. Harrisson 1967) }\end{array}$ & $\begin{array}{c}\text { Re-Classified } \\
\text { Burial Type } \\
\text { (Lloyd-Smith 2009) }\end{array}$ & Age / Sex & $\begin{array}{c}\text { Depth } \\
\text { (inches / metre) }\end{array}$ & Burial Group \\
\hline 25 & Flexed & Flexed / tight & $\mathrm{MA} / \mathrm{M}$ & $32 " / 0.81 \mathrm{~m}$ & 2 \\
\hline 27 & Flexed & Flexed / tight & $\mathrm{A} / ?$ & $30 " / 0.76 \mathrm{~m}$ & 1B \\
\hline 54 & Mutilation & Seated / charred & YA / M & $36 " / 0.91 \mathrm{~m}$ & 3 \\
\hline 77 & Flexed & Flexed / tight & YA / F & 28" / $0.71 \mathrm{~m}$ & $1 \mathrm{~B}$ \\
\hline 82 & Mutilation & Secondary / cremated & YC / ? & $36 " / 0.91 \mathrm{~m}$ & 1 \\
\hline 83 & Seated & Flexed / seated & YA / M & $36 " / 0.91 \mathrm{~m}$ & 1 \\
\hline 84 & Flexed & Flexed / tight & YA / M & $36 " / 0.91 \mathrm{~m}$ & 1 \\
\hline 87 & Flexed & Flexed / tight & $\mathrm{MA} / \mathrm{F}$ & $36 " / 0.91 \mathrm{~m}$ & 1 \\
\hline $88 a$ & Mutilation & Flexed / decapitated? & $A ? / ?$ & $48 "$ / $1.22 \mathrm{~m}$ & 1 \\
\hline $88 b$ & Flexed & Flexed / tight & $\mathrm{OC} / ?$ & 42" / 1.07 m & $1 \mathrm{~A}$ \\
\hline 89 & Flexed & Flexed / tight & YA / ? & $25 " / 0.64 \mathrm{~m}$ & 1 \\
\hline 92 & Mutilation & Secondary / unburnt & $\mathrm{OC} / ?$ & $48 "$ / $1.22 \mathrm{~m}$ & $1 \mathrm{~B}$ \\
\hline 93 & Mutilation & Flexed / decapitated? & YA / ? & $32 "$ / $0.81 \mathrm{~m}$ & $1 \mathrm{~B}$ \\
\hline 141 & Seated & Seated / charred & $\mathrm{OC} / \mathrm{F}$ & $18 " / 0.46 \mathrm{~m}$ & 3 \\
\hline 145 & Flexed & Flexed / tight & YC / ? & $32 "$ / $0.81 \mathrm{~m}$ & 2 \\
\hline 146 & Seated & Secondary / unburnt & $A / F$ & $20 " / 0.51 \mathrm{~m}$ & 2 \\
\hline 147 & Seated & Seated / charred & $A / F$ & 36" / $0.91 \mathrm{~m}$ & 3 \\
\hline 148 & Flexed & Flexed / tight & $A / M$ & $36 "$ / $0.91 \mathrm{~m}$ & 2 \\
\hline 155 & Flexed & Flexed / decapitated & $A / F$ & $18 "$ / $0.46 \mathrm{~m}$ & 4 \\
\hline 156 & Mutilated & Flexed / decapitated? & $A / F ?$ & $12 "$ / $0.30 \mathrm{~m}$ & 4 \\
\hline 170 & Flexed & Flexed / tight & $\mathrm{A} / ?$ & $50 " / 1.27 \mathrm{~m}$ & $1 \mathrm{~A}$ \\
\hline 171 & Flexed & Flexed / tight & $\mathrm{A} / ?$ & $44 " / 1.12 \mathrm{~m}$ & $1 \mathrm{~A}$ \\
\hline 172 & Flexed & Flexed / tight & $\mathrm{A} / \mathrm{M}$ & 39" / 0.99 m & $1 \mathrm{~A}$ \\
\hline 173 & Flexed & Flexed / ? & A / ? & $46 "$ / $1.17 \mathrm{~m}$ & $1 \mathrm{~A}$ \\
\hline 176 & Cremation & Secondary / cremated & $? / ?$ & $40 " / 1.07 \mathrm{~m}$ & 1 \\
\hline
\end{tabular}

Table 3. Early Holocene burials in the West Mouth, Niah Cave, Sarawak. Age and sex data supplied by John Krigbaum. (Age status: YC. younger child [6 months-6 yrs]; OC. Older child [7-12 yrs]; YA. Young adult [18-25 yrs]; MA. Middle adult [26-35 yrs]; A. adult [18-55 yrs]. Sex: M. male; M? probable male; F. female; F? probable female; ? sex unknown)

single earthenware sherd found above $24 "(0.60 \mathrm{~m})$. An early Holocene date for B92 is also suggested. Burials where the term mutilation appears appropriate are B144, $\mathrm{B} 153$, and B157, all of which contained articulated portions of human remains. In sub-surface burials B153 and B157, articulated portions of vertebrae were overlain by disarticulated remains, and Neolithic earthenware pottery was found underneath skeletal remains. The term 'semiarticulated secondary burials' has been proposed for these and they are interpreted as belonging to a post-Neolithic phase of burial in the cave (Lloyd-Smith 2013).

\section{Re-classification}

Four types of early Holocene burial in Niah Cave are now defined: primary flexed, primary seated, secondary unburnt, and secondary cremated (Table 3). For convenience, primary burials are hereafter referred to by their second order criteria.

Burials originally classified as flexed, seated, or mutilated, and earlier thought to be pre-Neolithic (B. Harris- son 1967), but which now are proposed to belong to the Neolithic or later, or are discounted altogether, are listed in Table 4.

\section{SPATIAL AND TEMPORAL PATTERNING IN} EARLY HOLOCENE BURIAL AT NIAH CAVE

By visual inspection of the site plan several discrete and overlapping burial clusters can be identified (Table 5; Figure 11). The main burials form two distinct clusters, one under the rock overhang (hereafter termed Burial Group 1) and the other, Burial Group 2, located several metres to the south at the front of the cave mouth. The commonest form of burial consisted of the body being placed in a pit in flexed position. In some instances pigmentation was applied to the skulls. A grave pit visible in archive photographs of flexed burial B25, and the basal portion of flexed burial B84's burial pit preserved in a plinth of sediment under the overhang, indicate that the dead were placed in substantial graves at least $60 \mathrm{~cm}$ deep. 


\begin{tabular}{|c|c|c|c|c|c|}
\hline $\begin{array}{l}\text { Burial } \\
\text { Number }\end{array}$ & $\begin{array}{l}\text { Original Classification } \\
\text { (B. Harrisson 1967) }\end{array}$ & $\begin{array}{c}\text { Re-Classified } \\
\text { Burial Type } \\
\text { (Lloyd-Smith 2009) }\end{array}$ & Age / Sex & $\begin{array}{c}\text { Depth } \\
\text { (inches / metre) }\end{array}$ & Note \\
\hline 17 & Flexed & Secondary / unburnt & $\mathrm{OC} / \mathrm{F} ?$ & $15 " / 0.38 \mathrm{~m}$ & Neolithic \\
\hline 23 & Flexed & ?Flexed / ? & $A ? / ?$ & $22 "$ / $0.56 \mathrm{~m}$ & - \\
\hline 34 & Flexed & Flexed / loose & YA? / F? & 3" / $0.08 \mathrm{~m}$ & Post-Neolithic \\
\hline 73 & Mutilation & Casual burial & $A / F$ & $106 " / 2.70 \mathrm{~m}$ & ‘Deep Skull’ \\
\hline 79 & Mutilation & Casual burial & $\mathrm{A} / \mathrm{M} ?$ & $50 " / 1.27 \mathrm{~m}$ & - \\
\hline 81 & Mutilation & Secondary / skull & YA / ? & $16 " / 0.41 \mathrm{~m}$ & Post-Neolithic \\
\hline 95 & Mutilation & Secondary / unburnt & A / ? & 5" / $0.13 \mathrm{~m}$ & ?Post-Neolithic \\
\hline 97 & Mutilation & Discounted & - & 42" / 1.07 m & - \\
\hline 119 & Mutilation & Secondary / skull & $A / M$ & 2" / $0.06 \mathrm{~m}$ & Neolithic \\
\hline 130 & Flexed & ?Flexed / ? & $? / ?$ & $12 "$ / $0.30 \mathrm{~m}$ & Neolithic \\
\hline 153 & Mutilation & $\begin{array}{l}\text { Secondary burial / } \\
\text { semi-articulated }\end{array}$ & $A / F ?$ & 8" / $0.20 \mathrm{~m}$ & Post-Neolithic \\
\hline 157 & Mutilation & $\begin{array}{l}\text { Secondary burial / } \\
\text { semi-articulated }\end{array}$ & $\mathrm{YC} / ?$ & $12 " / 0.30 \mathrm{~m}$ & Post-Neolithic \\
\hline $163 / 166$ & Mutilation & $\begin{array}{c}\text { Discounted / } \\
\text { disturbed fragments }\end{array}$ & - & $12 "$ / $0.30 \mathrm{~m}$ & - \\
\hline $167 / 168$ & Mutilation & $\begin{array}{l}\text { Discounted / } \\
\text { disturbed fragments }\end{array}$ & - & 5" / $0.13 \mathrm{~m}$ & - \\
\hline 205 & Flexed & Flexed / tight & $\mathrm{A} / ?$ & $36 " / 0.90 \mathrm{~m}$ & Early Neolithic \\
\hline
\end{tabular}

Table 4. Sixteen West Mouth Niah Cave burial numbers originally allocated to burial types flexed, seated, and mutilations, and phased to the pre-Neolithic (B. Harris-son 1967), which after re-classification are interpreted as not dating to the early Holocene or are discounted as burials. Age and sex data supplied by John Krigbaum. (Age status: YC. younger child [6 months-6 yrs]; OC. Older child [7-12 yrs]; YA. Young adult [18-25 yrs]; MA. Middle adult [26-35 yrs]; A. adult [18-55 yrs]. Sex: M. male; M? probable male; F. female; F? probable female; ? sex unknown)

\section{Burial Group Description}

1

Thirteen flexed burials, two secondary burial cremations, and one unburnt secondary burial clustered under and around overhang at northwest corner of cave mouth. All burials found at depths of between $0.64 \mathrm{~m}$ and $1.27 \mathrm{~m}$. Two possible sub-groups identified: Group 1A comprising a cluster of six flexed burials under north end of overhang; Group 1B formed by cluster of three flexed burials at southern end of overhang.

Open-air cluster of three flexed burials, and possibly one unburnt secondary burial (B146), located at end of slight ridge-line extending out from cave interior. Found at depths of between $0.51 \mathrm{~m}$ and 1.12 m. Spatially overlapping with Burial Group 3.

Seated burials: B54, B141, and B147. Located along a ridge from B147 in the vicinity of Burial Group 


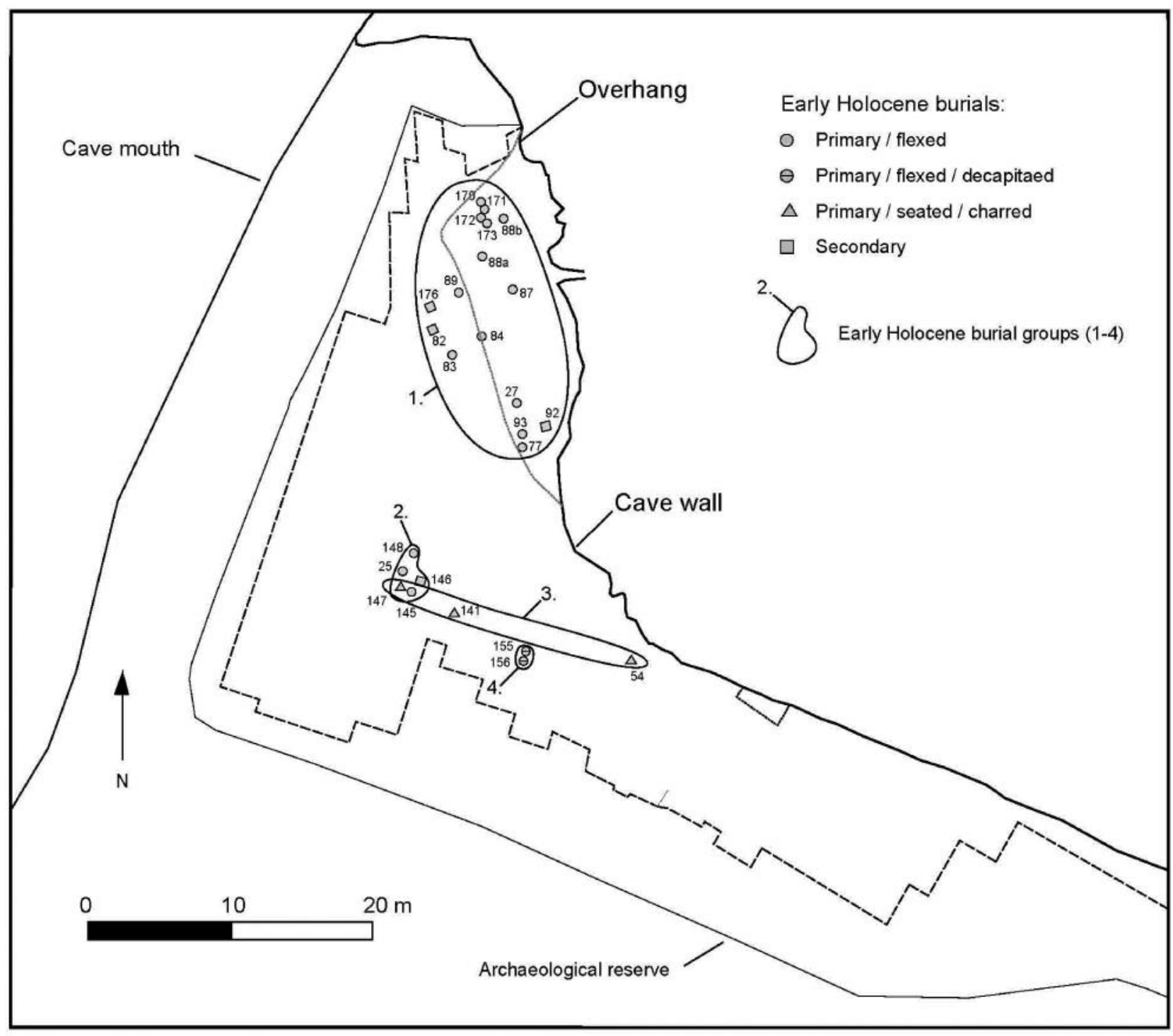

Figure 11. Proposed early Holocene burial groups in the West Mouth, Niah Cave. (Illustration: L. Lloyd-Smith).

\begin{tabular}{|c|c|c|c|c|c|}
\hline Burial / Location & Sample No. & Material & C14 Date & $\begin{array}{l}\text { Cal. Date Range } \\
\text { (2 Sigma) }\end{array}$ & Ref. \\
\hline $\mathrm{B} 176$ & OxA-X-2251-39 & Cremated bone & $17,460 \pm 70 \mathrm{BP}$ & $19,283-18,467$ BC & 3 \\
\hline YE3 60" - 66" & OxA-15163 & Charcoal & $35,890 \pm 250 \mathrm{BP}$ & $39,671-38,549 \mathrm{BC}$ & 4 \\
\hline YE3 48" - 54" & OxA-15162 & Charcoal & $13,745 \pm 55 \mathrm{BP}$ & $15,093-14,754 \mathrm{BC}$ & 4 \\
\hline W3 24" - 36" & OxA-15157 & Charcoal & $9995 \pm 40 \mathrm{BP}$ & $9750-9321 \mathrm{BC}$ & 4 \\
\hline YE3 30" - 36" & OxA-15161 & Charcoal & $7606 \pm 35 \mathrm{BP}$ & $6506-6401 \mathrm{BC}$ & 4 \\
\hline YE3 12" - 18" & OxA-15159 & Charcoal & $2676 \pm 27 \mathrm{BP}$ & $896-800 \mathrm{BC}$ & 4 \\
\hline YE3 18" - 24" & OxA-15160 & Charcoal & $2619 \pm 27 \mathrm{BP}$ & $827-774$ BC & 4 \\
\hline B155 & $\mathrm{N}-1357$ & Bone collagen & $7850 \pm 175$ BP & $7291-6395$ BC & 1 \\
\hline B92 & $\mathrm{N}-1346$ & Bone collagen & $7140 \pm 165$ BP & $6368-5724$ BC & 1 \\
\hline $\mathrm{B} 147$ & $\mathrm{~N}-1355$ & Bone collagen & $7020 \pm 135 \mathrm{BP}$ & $6207-5659 \mathrm{BC}$ & 1 \\
\hline B77 & $\mathrm{N}-1343$ & Bone collagen & $3580 \pm 70 \mathrm{BP}$ & $2135-1746 \mathrm{BC}$ & 1 \\
\hline $\mathrm{B} 147$ & GrN-7203 & Bone apatite & $13,640 \pm 130 \mathrm{BP}$ & $15,121-14,445 \mathrm{BC}$ & 2 \\
\hline B146 & $\mathrm{N}-1354$ & Bone apatite & $11,400 \pm 1550$ BP & $16,618-7940 \mathrm{BC}$ & 1 \\
\hline B54 & $\mathrm{N}-1334$ & Bone apatite & $10,600 \pm 510 \mathrm{BP}$ & $11,649-8930 \mathrm{BC}$ & 1 \\
\hline B83 & $\mathrm{N}-1344$ & Bone apatite & $8000 \pm 225 \mathrm{BP}$ & $7487-6465$ BC & 1 \\
\hline
\end{tabular}

Table 6. Radiocarbon dates discussed in this paper, ordered by sample material. Calibrated date ranges produced using OxCal v.4.10 with the IntCal 09 calibration curve. (References: 1. T. Harrisson 1975; 2. Brooks et al. 1977; 3. Lloyd-Smith 2009; 4. Barker 2013). 


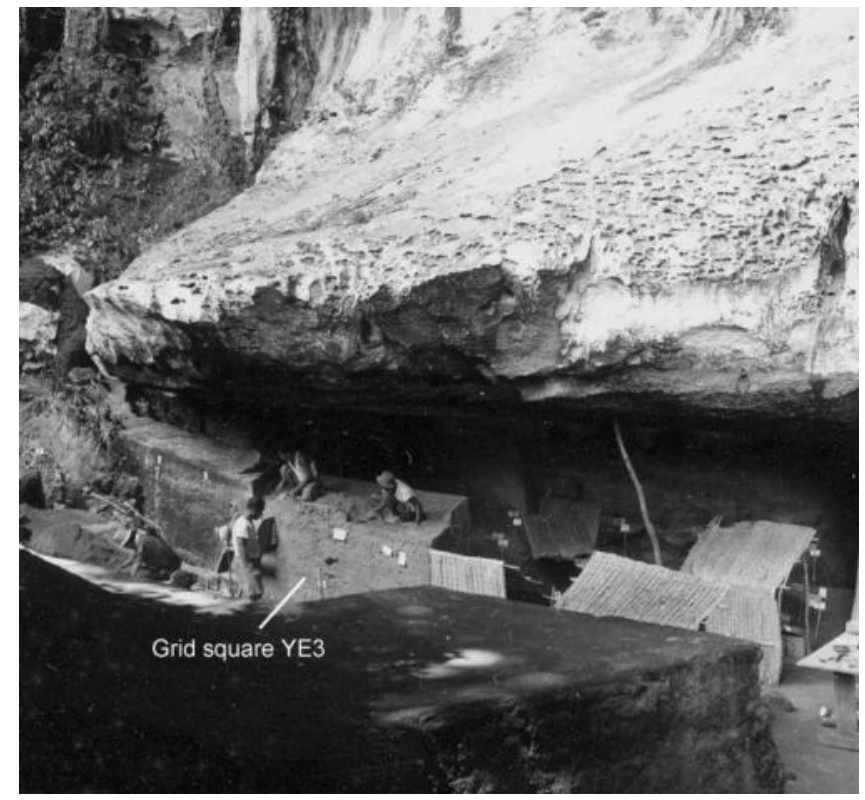

Figure 12.Excavation of grid YE3 under the overhang in the front of the West Mouth, Niah Cave. (Photograph courtesy of Sarawak Museum)

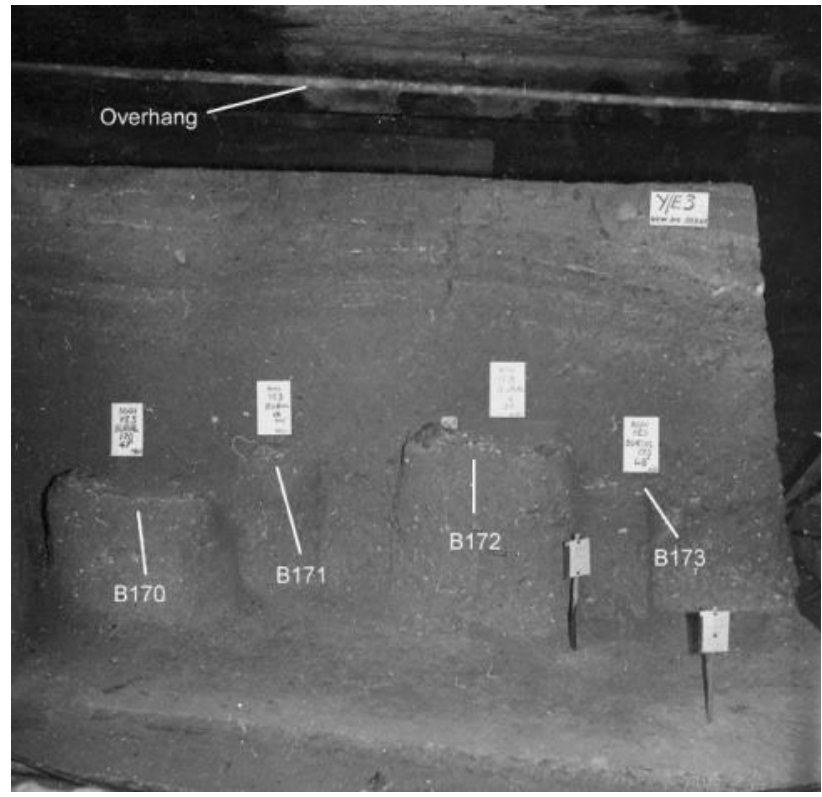

Figure 13. West-facing section of baulk between grid square $Y E 3$ and squares $Y 3$ and $Y 4$, with exposed in situ flexed burials B170, B171, B172, and B173 indicated. (Photograph courtesy of Sarawak Museum)

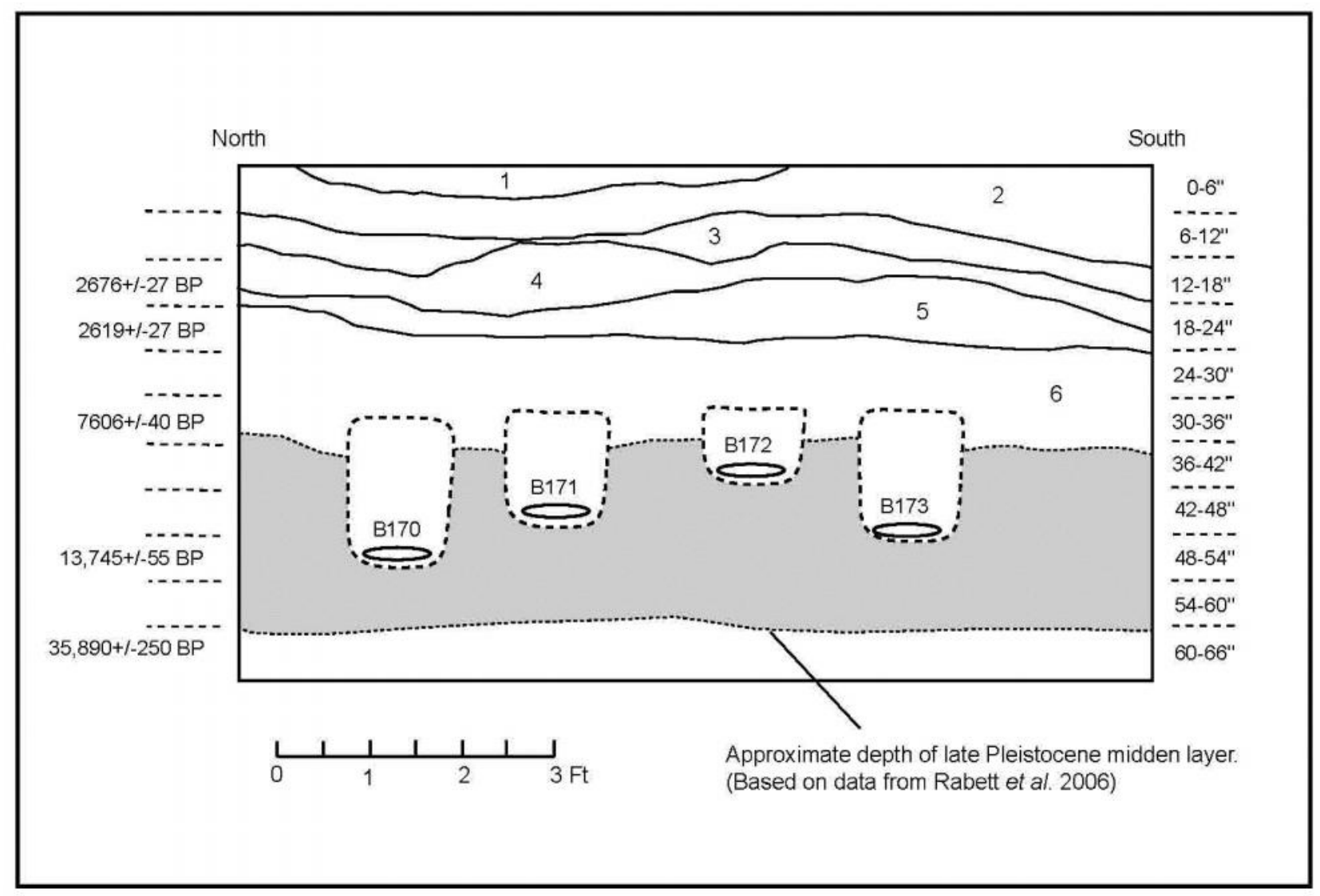

Figure 14. West-facing section of baulk between grid squares YE3 and squares Y3 and Y4 Positions of flexed burials B170, B171, $B 172$, and B173 made according to original grid plan drawing and their respective depth. Size and depth of reconstructed grave cuts based upon that observed for B25 discussed in the text. Excavation spit depths marked and radiocarbon dates shown at their respective depths. Layer descriptions made in 1965: 1. Dark brown soil; 2. Light brown soil; 3. Upper layer of striped black ash and charcoal; 4. Lower layer of striped ash and charcoal; Shell layer with white spotted ash powdery stones; 6. Light brown soil with yellow clay. (Adapted from field drawing in the Harrisson Excavation Archive: Sarawak Museum). 
The relative positions of several burials in Burial Group 1 can also be reconstructed from photographs and drawings in the Harrisson Excavation Archive. Their positions, and $14 \mathrm{C}$ dates from charcoal samples from the Archive (submitted by the Niah Caves Project; Barker 2013) suggest that the sediments excavated by the Harrissons under the overhang above their $24 "(0.60 \mathrm{~m})$ spit were broadly contemporary with the later phases of the Neolithic cemetery (Figures 12, 13, 14; Table 6). A 14C date of $7606 \pm 35 \mathrm{BP}$ or 6506-6401 cal. BC (OxA-16161) from charcoal from spit 30"-36" $(0.76-0.90 \mathrm{~m})$ provides the best estimate for the upper limit of the date range of the early Holocene flexed burials here, and a date of $9995 \pm 40$ BP or $9750-$ 9321 cal. BC (OxA-15157) from spit 24"-36" (0.60-0.90 $\mathrm{m})$ from nearby grid square $\mathrm{W} 3$ provides the best indication of the lower limit. This group of flexed burials was dug into the earlier bone midden layer dated to the late Pleistocene (Rabett et al. 2006), indicated by the shaded horizon in Figure 14.

As part of the original study of the West Mouth burials by Shelagh and Richard Brooks, a series of radiocarbon dates was obtained from samples of bone collagen and apatite (Brooks et al. 1977; T. Harrisson 1975). The reliability of the apatite samples was immediately questioned because they produced the oldest dates with the widest error ranges, between 15,121 BC and $6400 \mathrm{BC}$ (Brooks et al. 1977: 28). The reliability of the bone collagen dates has also been questioned (Spriggs 1989). However, it can be noted that three of the four bone collagen dates on deeply stratified burials (B92, B147, and B155) fall in the date range 7291-5659 cal. BC, which is within that now proposed on stratigraphic grounds.

Although flexed burial appears to have been the normative or customary rite, more elaborate forms of secondary burial were also practised whereby bodies were brought to the West Mouth to be buried there as part of a secondary process following an earlier primary burial or exposure elsewhere. Some bodies were cremated, others consisted of unburnt bones. Examples of the former in Burial Group 1 are burials B82 and B176, an example of the latter is B92 at the back of the overhang. A sample of cremated bone from $\mathrm{B} 176$ produced a radiocarbon date of $17,460 \pm 70$ BP or 19,283-18,467 ca. BC (OxA-X-225139). After chemical preparation this sample contained four times as much carbon as the other cremated bone samples (from the Neolithic cemetery), indicating that the sample had been contaminated through the absorption of old carbon (Tom Higham pers. comm.). The location of B176 at the front of the cave and just outside the secondary overhang would have exposed the burial to increased rainwater percolation. An early Holocene date is proposed for these two cremations based on their depth and location close to the overhang; a focus point of early Holocene burial. The spatial congruence of these two cremation burials, and their location at a distance from other flexed burials, suggest that they are contemporaneous to one another and therefore may constitute a distinct chronological phase in burial practice within the early Holocene.
At the back of the overhang, burial B92 yielded a bone collagen date of $7140 \pm 165 \mathrm{BP}$ or $6368-5724$ cal. BC (N1346; Brooks et al. 1977), which agrees with the proposed early Holocene date for this burial based upon stratigraphic evidence. An early Holocene date is also proposed for the three deeply stratified seated/charred burials B54, B141, and B147 that form Burial Group 3. Two bone apatite dates (GrN-7203: T. Harrisson 1975; N1334: Brooks et al. 1977) can be rejected, but B147 later yielded a bone collagen date of $7020 \pm 135$ BP or 62075659 cal. BC (N-1355). The complicated nature of the burial rites of these rare burials, involving the placing of the body on a fire lit on the base of a large and deep pit, suggests exclusive treatment for selected members of the community. These burials are widely distributed at the site, including far back from the cave mouth. Their spatial separation from the other early Holocene burials is mirrored in their significantly different carbon isotope signatures that suggest an open-canopy, possibly maritime, subsistence (Krigbaum 2001: 193), compared with the closed-canopy environments of the early Holocene flexed burials. On the evidence of the single collagen date it is possible that the seated burials post-date the flexed burials, in which case the B141 isotopic signature might reflect an open-canopy diet associated with the midHolocene high-sea stand when the limestone massif in which the Niah Caves are located was a coastal headland, or possibly an off-shore island (Hunt and Rushworth 2005). If the seated burials are more or less contemporary with the flexed burials, the difference in isotopic signatures would appear to indicate differences in lifestyle, occupation, settlement locale, and/or diet.

The two flexed/decapitated burials (B155 and B156), lie side by side, and a distance from the open-air cluster of flexed burials in Burial Group 2. The hands and feet of these two burials appear to have been bound. B155 yielded a bone collagen date of 7850 $\pm 175 \mathrm{BP}$ or 7291-6395 cal. BC (N-1357; Brooks et al. 1977). The pairing and back-to-back positioning of these two individuals indicate that their graves were dug at the same time. Their location away from the front of the cave mouth also suggests that a deliberate spatial (and symbolic?) distance was maintained between this burial event and those of Burial Group 2. Even if the two burial areas were not exactly contemporaneous, it is reasonable to assume that those who performed the B155 and B156 decapitation burials belonged to a community for whom flexed burial was the normative rite and who knew the West Mouth as a place where people had lived and been buried with traditional rites. The spatial separation of the B155 and B156 burials may have symbolized a need to create social distance in death. Such an interpretation is further evoked by the separation of the head from the body, an action that divided a whole social being into parts.

The creation of distinct clusters of interments in the West Mouth indicates the repeated use of the site for burial over short periods of several centuries, with intervals in between, rather than frequent occupation and site visitation over millennia. Applying this interpretation to the 
refined c. 9750-6400 $\mathrm{BC}$ date range based on stratigraphic data, it appears that within this c.3350 year period, the West Mouth was a focal point in the landscape to which people repeatedly returned and occupied for relatively short periods of time. When people came to bury their dead they knew where the graves should be placed in relation to earlier ones, remembering the locations and possibly the identities of particular burials. An indication of the possible spatial association of burials is the occurrence of similar items of material culture (rhinoceros bone and teeth) in the adjacent burials B27 and B83. Whether by direct 'signposts' such as wooden grave markers or by word of mouth, it appears that ancestral identities were recognised and respected.

Lastly, if the radiocarbon dates on bone collagen may be given any credence, and their congruence with the new secure date range based on charcoal dates lends them some support, a conservative estimate would place the early Holocene burials within the latter half of the proposed period, that is to say short periods of intensive occupation and burial within the $c .1650$ year period $c .7300-$ $5650 \mathrm{BC}$.

\section{EARLY HOLOCENE BURIALS IN SOUTHEAST ASIA}

A scarcity of detailed published data on early Holocene burials from the wider region means it is not possible to state a total precise number. However, a brief review of the more widely available regional English-language literature indicates that the early Holocene burials from the West Mouth have parallels elsewhere in Southeast Asia (see Fig. 1). In Kalimantan (Indonesian Borneo) at the site of Kimanis in the upper Birang river, two tightly flexed burials were discovered. Pieces of fossilised wood covered one of the bodies, possibly marking the location of the burial (Arifin 2004: 156). No direct radiocarbon dates were possible on the burials, but their stratigraphic positions indicate a date in the early Holocene (Arifin 2004). The two flexed burials were located only a few metres apart and their close proximity suggests a concentration of burial within specific areas of the cave. Further flexed burials are reported from Gua Tengorak in Western Kalimantan and are also thought to date to the Early Holocene (Arifin 2006).

In the Gunung Sewu mountains on the south coast of East Java, primary flexed and well as secondary burials, including cremations, have been excavated which are thought to date to the Early Holocene (Simanjuntak 2002). At the sites of Song Terrus, Song Keplek, and Gua Braholo, deeply stratified tightly flexed burials were placed into Early Holocene midden layers. Calibrated radiocarbon dates obtained on charcoal from comparable levels range between c.10,000 BC and $4300 \mathrm{BC}$ (Simanjuntak 2002). A extended primary burial was also discovered at Song Keplek and charcoal from near the burial was dated to $7020 \pm 120$ or $6250-5550$ cal. BC (no sample number published; Détroit 2006: 199). This burial was found at a greater depth than the flexed burial at the site and Détroit accepts the early date. However, the well preserved condition of the extended burial suggests that the charcoal sample may have been re-deposited from earlier stratigraphy.

The flexed burials are described as tightly bound, often positioned with their feet underneath the pelvis and hands 'holding' the face (Détroit 2006). So far only isolated flexed burials have been discovered and no spatial burial groups are evident. However, at the site of Gua Braholo, along with the flexed burial, a secondary burial was found at $2.30 \mathrm{~m}$ depth. While the remains were unburnt, they had been placed into a pit on the base of which was a concentration of ash and charcoal, suggesting that fire was part of the preparatory funerary rituals (Détroit 2006: 196). Charcoal from this grave produced a radiocarbon date of $8710 \pm 170 \mathrm{BP}$ or $8300-7500$ cal. BC (no sample number provided; Détroit 2006: 199). This date confirms that complicated secondary burial practices were broadly contemporaneous with primary flexed burial, similar to what I propose for Niah Cave. The light charring of the upper surfaces of a primary flexed burial at Song Keplek is also suggestive of graveside rituals involving fire (Détroit 2006: 190). Moreover, at the nearby site of Gua Lawa a secondary burial cremation was found at $2.50 \mathrm{~m}$ depth. The burial deposit was contained in a circular area measuring 0.40-0.50 m across, and while no direct or indirect absolute date can be assigned to the burial, the 'Pre-Neolithic' date proposed by Détroit (2006: 198-199) is reasonable given the burial's depth

Early Holocene cremations have also been discovered at Ille Cave on the northeast coast of Palawan in the Philippines (Lewis et al. 2008). Two radiocarbon dates on cremated bone samples calibrate to between 7520 and $7050 \mathrm{BC}$ (Lewis et al. 2008: 326). This date range is remarkably similar to the date for the Gua Braholo secondary burial, and in conjunction with the proposed preNeolithic secondary burials, both unburnt and cremated at Niah Cave, indicate the widespread occurrence of these complicated mortuary practices already during the Early and mid-Holocene.

Seated burials were a common form of burial for Da But coastal communities in northern Vietnam, where over one hundred such burials are reported from cemeteries and shell midden sites dating to between c.6000 and 3000 BC (Viet and Oanh 2003: 83-84).

The earliest evidence for occupation of the interior of the Malay Peninsula is significantly later than for the rest of the Indo-Malaysian Archipelago (Bellwood 1993), and the earliest dates for flexed burials at inland site along the Malay Peninsula fall a few millennia after initial colonization. Many primary flexed burials and secondary burials are known from inland cave sites along the Malay Peninsula dating to the Early and mid-Holocene, for example at Gua Cha, Gua Gunung Runtuh, Gua Teluk Kelawar, and Gua Peraling (Zuraina 2005). At smaller cave sites, single flexed burials are commonly found, while at the large rock shelf of Gua Cha eighteen flexed burials have been documented by numerous excavations (Adi 1985; Noone 1939; Sieveking 1954). Combining the reports from the various excavations, these burials appear to form spatially 
delimited groups, reminiscent of what we see in Niah Cave. (A complete spatial analysis of the Gua Cha burials based upon a compilation of all published site drawings and data is currently underway by the author).

Lastly, mention should also be made to the spectacular burial at Liang Lembudu, on the Aru Islands (Bulbeck 2005), dated to c.17,000 year BP. This burial appears to have been buried in a tightly flexed position, after the removal of the hands and feet. Later, the grave was reopened and the body manipulated, the limb bones handled and then re-buried. A boulder directly overlying the burial may have been placed a grave marker.

\section{CONCLUSION}

Despite a substantial quantity of human skeletal material, including the Deep Skull, found in stratified layers in the West Mouth of Niah Cave dating from 40,000 to 15,000 years ago (Rabett et al. 2006), discrete and definable burial features do not occur until the Early Holocene. Based upon an assessment of the stratigraphic locations of the flexed and seated burials, their refined date range is proposed to be $c .10,000-5500 \mathrm{BC}$. In comparison with the immense period of human presence at the site of over 25,000 years in the Pleistocene, when mortuary practice appears to have simply involved the incorporation of the dead into the general midden area, the commencement of discrete burial signifies a change in the perception of the dead and cultural attitudes towards their appropriate treatment. Through the creation of individual graves, the dead were incorporated into the historical fabric of occupation sites as focal ancestral features.

A similar picture is emerges from the regional data, for example, on Java where although there are many sites with Pleistocene deposits dating to 40,000-12,000 BP, so far no human remains, let alone burials, dating to this period have been discovered (Simanjuntak 2002: 90). From further afield and slightly older, an exception is the Last Glacial Maximum human burial at Liang Lembudu, on the Aru Islands on what would have been the northwest coast of Sahul land (Bulbeck 2005). In this light, Burial B79 at Niah, an articulated left foot and assorted skeletal elements found in a midden layer dated to $c .16,000$ years ago, shares broad similarities with the manipulated Lembudu burial, suggesting common ritual practices spanned the island divide between the two continental landmasses during the late Pleistocene.

In the post-Glacial period, more restricted regional patterns emerge. Across the eastern half of IndoMalaysian Archipelago there appears to exist a broadly contemporaneous horizon defined by the appearance of discrete burial. Both primary and secondary burial were practiced at the same locations, and as far as can be told within the limitations of archaeological chronologies, as a set of contemporary or overlapping funerary practices. Burials were placed in tightly flexed (bound?) positions in graves often dug into earlier occupation/midden layers. At larger rock shelters and cave sites spatial clusters are found. The presence of both primary and secondary burials suggests a combination of both 'opportunistic' mortu- ary practice, whereby any member of the community was interred if the community happened to be camped at the site when that person died, and possibly more selective practices whereby selected members of the community who had died elsewhere were brought back to a cave for secondary (special) burial. The spatially restricted areas of burial may be seen as signalling that ancestral identities were maintained through the creation of specific localized burial groups. Secondary burial was widely practised, possibly as early as 8000 BC. Fire was a widespread aspect of Early Holocene secondary burial rituals, but the practice of fully cremating the corpse appears to be geographically restricted to more coastal sites lying along the eastern sea-board of what was the Sunda Shelf. Finally, the practice of seated burial at Niah potentially adds a further dimension to a maritime sphere of interaction across the South China Sea between north Borneo and Vietnam which has been suggested by David Bulbeck: initially in the terminal Pleistocene distribution of edge ground tools in the Bacsonian of North Vietnam and those at Niah Cave, and later by the earlier dates of basket impressed pottery and rice found at Da But cultural sites, and the material seen at the site of Gua Sireh in Sarawak (Bullbeck 2008; Datan 1993).

This paper has highlighted broad regional patterns in Early Holocene burial practice across Island Southeast Asia. The commencement of discrete burial may be seen as a significant chronological marker in the eastern half of Island Southeast Asia, reflecting a shared cultural shift in peoples' relationship with their dead. Varied, complicated, and overlapping burial practices evolved in tandem, and add further dimensions to early Holocene spheres of cultural interaction in the region.

\section{ACKNOWLEDGEMENTS}

This paper is based upon doctoral research which led on from my involvement in the Niah Caves Project, directed by Prof. Graeme Barker, whom I would like to thank for his supervision and guidance. Research permission was granted by the Chief Minister's Department of Sarawak, and I would like to thank the Director of the Sarawak Museum, Ipoi Datan, for his support. I also thank Barbara Harrisson for her enthusiasm and support of my research on the prehistoric burials at Niah. Thanks also to John Krigbaum for supplying the osteological data on the Niah burials. The doctoral research was funded by the Arts and $\mathrm{Hu}-$ manities Research Council, with additional fieldwork grants from the Evans Trust and St Edmund's College (Cambridge).

\section{REFERENCES}

Adi Taha 1985. The re-excavation of the rockshelter of Gua Cha, Ulu Kelatan, West Malaysia, Federation Museums Journal 30: 1-134.

Anderson, D. 1997. Cave archaeology in Southeast Asia, Geoarchaeology, 12(6): 607-38.

Arifin, K. 2004. Early human occupation of the East Kalimantan rainforest (the upper Birang River region, Berau). Unpublished $\mathrm{PhD}$ dissertation, Australian National University

Arifin, K. 2006. The Austronesians in Borneo. In. T. Simanjuntak, I. Pojoh and M. Hisyam (eds) Austronesian Diaspora 
and the Ethnogeneses of People in Indonesian Archipelago: 146-162. Jakarta: LIPI Press.

Barker, G. (ed.) 2013. Prehistoric Foraging and Farming in Island Southeast Asia: The Archaeology of the Niah Caves, Sarawak, Volume 1. Cambridge: McDonald Institute for Archaeological Research.

Barker, G., Piper, P.J., and Rabett, R.J. 2009. Zooarchaaeology at the Niah Caves: Context and Research Issues. International Journal of Osteoarchaeology 19(4): 447-463.

Barker, G., Barton, H., Bird, M., Cole, F., Daly, P., Dykes, A., Gilbertson, D., Hunt, C., Lewis, H., Lloyd-Smith, L., Manser, J., Mclaren, S., Menotti, F., Paz, V., Piper, P., Pyatt, B., Rabett, R., Reynolds, T., Stephens, M., Thompson, G. and Trickett, M. 2003. The Niah Cave Project: the fourth (2003) season of fieldwork, Sarawak Museum Journal 58: 45-199.

Barker, G., Barton, H., Bird, M., Daly, P., Datan, I., Dykes, A., Farr, L., Gilbertson, D., Harrisson, B., Hunt, C., Higham, T., Krigbaum, J., Lewis, H., Mclaren, S., Paz, V., Pike, P., Piper, P., Pyatt, B., Rabett, R., Reynolds, T., Rose, J., Rushworth, G., Stephens, M., Stringer, C. and Thompson, G. 2007. The 'human revolution' in tropical Southeast Asia: the antiquity of anatomically modern humans, and of behavioural modernity, at Niah Cave (Sarawak, Borneo). Journal of Human Evolution 52: 243-261.

Barker G, Barton H, Beavitt P, Bird M, Daly P, Doherty C, Gilbertson D, Hunt C, Krigbaum J, Lewis H, Manser J, McClaren S, Paz V, Piper P, Pyatt B, Rabett R, Reynolds T, Rose J, Rushworth G, Stephens M. 2002. Prehistoric Foragers and Farmers in South-east Asia: Renewed Investigations at Niah Cave, Sarawak. Proceedings of the Prehistoric Society 68: 147-164.

Barton H and Paz V. 2007. Subterranean diets in the tropical rainforest of Sarawak, Malaysia. In Denham TP, Iriarte J and Vrydaghs L. (eds) Rethinking Agriculture: Archaeological and ethnoarchaeological perspectives: 50-77. California: Left Coast Press Inc.

Bellwood, P. 1993. Cultural and biological differentiation in peninsular Malaysia: the last 10,000 years. Asian Perspectives 32(1): 37-60.

Bloch, M., and Parry, J. 1982. Death and the Regeneration of Life. Cambridge: Cambridge University Press.

Brooks, S.T., R. Helgar, and R. H. Brooks. 1977. Radiocarbon dating and palaeoseriology of a selected burial series from the Great Cave of Niah, Sarawak, Malaysia. Asian Perspectives 20: 21-31.

Bulbeck, D. 2005. The last glacial maximum human burial from Liang Lambudu in Northern Sahulland. In. S. O'Connor, M. Spriggs and P. Veth (eds) The Archaeology of the Aru Islands, Eastern Indonesia: 255-294. Canberra: The Australian National University.

Bulbeck, D. 2008. An integrated perspective on the Austronesian diaspora. Australian Archaeology 67: 31-51.

Datan, I. 1993. Archaeological excavations at Gua Sireh (Serian) and Lubang Angin (Gunung Mulu National Park), Sarawak, Malaysia. Special Monograph No. 6, Sarawak Museum Journal 45: 1-192.

Détroit, F. 2006. Homo sapiens in southeast asian archipelagos: the Holocene fossil evidence with special reference to funerary practices in East Java. In. T. Simanjuntak, I. Pojoh and M. Hisyam (eds) Austronesian Diaspora and the Eth- nogeneses of People in Indonesian Archipelago: 186-204. Jakarta : LIPI Press.

Harrisson, B. n.d.: B54. Field notebook Burial B54, Harrisson Excavation Archive, West Mouth, Niah Cave. Sarawak Museum: Kuching.

Harrisson, B. n.d.: B141. Field notebook Burial B141, Harrisson Excavation Archive: West Mouth, Niah Cave. Sarawak Museum: Kuching.

Harrisson, B. n.d.: B146. Field notebook Burial B146, Harrisson Excavation Archive: West Mouth, Niah Cave. Sarawak Museum: Kuching.

Harrisson, B. n.d.: B147. Field notebook Burial B147, Harrisson Excavation Archive: West Mouth, Niah Cave. Sarawak Museum: Kuching.

Harrisson, B. 1967. A classification of Stone Age burials from Niah great cave, Sarawak. Sarawak Museum Journal 15 (n.s. 30-31): 126-200.

Harrisson, T. 1970 The prehistory of Borneo. Asian Perspectives 13: $17-45$.

Harrisson, T. 1975 Early dates for "seated" burial and burial mating at Niah Caves, Sarawak (Borneo). Asian Perspectives 18: 161-165.

Hunt, C.O. and G. Rushworth. 2005. Cultivation and human impact at $6000 \mathrm{cal} \mathrm{yr} \mathrm{BP}$ in tropical lowland forest at Niah, Sarawak, Malaysian Borneo. Quaternary Research 64 (3): 460-468.

Huntington R. and Metcalf P 1979. Celebrations of Death. Cambridge: Cambridge University Press.

Krigbaum, J., 2001. Human Paleodiet in Tropical Southeast Asia: Isotopic Evidence from Niah Cave and Gua Cha. Unpublished PhD dissertation, New York University.

Krigbaum, J. 2005. Reconstructing human subsistence in the West Mouth (Niah Cave, Sarawak) burial series using stable isotopes of carbon. Asian Perspectives 44 (1): 73-89.

Lewis, H., V. Paz, M. Lara, H. Barton, P. Piper, J. Ochoa, T. Vitales, A.J. Carlos, T. Higham, L. Neri, V. Hernandez, J. Stevenson, E. C. Robles, A. Ragragio, R. Padilla, W. Solheim II, and W. Ronquillo. 2008. Terminal Pleistocene to mid-Holocene occupation and an early cremation at Ille Cave, Palawan, Philippines. Antiquity 82: 318-335.

Lloyd-Smith, L. 2009. Chronologies of the Dead: Later Prehistoric Burial Practice at the Niah Caves, Sarawak. Unpublished $\mathrm{PhD}$ dissertation, University of Cambridge.

Lloyd-Smith, L. 2013. The West Mouth Neolithic cemetery, Niah Cave, Sarawak, Proceedings of the Prehistoric Society Vol. 79: 105-136.

Lloyd-Smith, L., G. Barker, H. Barton, J. Cameron, F. Cole, C. Doherty, C. Hunt, J. Krigbaum, H. Lewis, J. Manser, V. Paz, P. Piper R. Rabbett, G. Rushwoth, and K. Szabó. 2013. 'Neolithic societies': c.4000-2000 years ago: Austronesian Farmers? In Graeme Barker (ed.) Prehistoric Foraging and Farming in Island Southeast Asia: The Archaeology of the Niah Caves, Sarawak, Volume 1, pp.255298. Cambridge: McDonald Institute for Archaeological Research Monographs.

Manser, J., 2005. Morphological Analysis of the Human Burial Series at Niah Cave: Implications for Late PleistoceneHolocene Southeast Asian Human Evolution. Unpublished $\mathrm{PhD}$ dissertation, New York University. 
Noone, H. D. 1939. Report on a new Neolithic site in Ulu Kelantan, Journal of the Federated Malay States Museums 15: $170-174$.

O'Connor, S. .2006 Unpacking the Island Southeast Asian Neolithic cultural package, and finding local compexity. In. E. A. Bacus, I. Glover and V. C. Piggot (ed.) Uncovering Southeast Asia's Past: Selected papers from the 10th International conference of the European Association of Southeast Asia Archaeologists: 74-87. Singapore: National University of Singapore.

Rabett, R., Piper, P. and Barker, G. 2006. Bones from 'Hell': preliminary results of new work on the Harrisson faunal assemblage from the deepest part of Niah Cave, Sarawak. In. E. A. Bacus, I. C. Glover and V. C. Pigott (eds) Uncovering Southeast Asia's past: selected papers from the 10th International Conference of the European Association of Southeast Asian Archaeologists: 46-59. Singapore: National University of Singapore Press.

Sieveking, G. D. G. 1954 Excavations at Gua Cha, Kelantan. 1954. Part 1, Federation Museums Journal 1-2: 75138.

Simanjuntak, T. 2002. Gunung Sewu in Prehistoric Times. Yogyakarta: Gadjah Mada University Press.
Soares, P., J.A. Trejaut, Loo Jun-Hun, C. Hill, M. Mormina, C.L.Lee, Y.-M.Chen, G. Hudjashov, P. Forster, V. Macaulay, D. Bulbeck, S. Oppenheimer, M. Lin, and M.B. Richards. 2008. Climate change and postglacial human dispersals in Southeast Asia. Molecular Biology Evolution 25(6): 1209-1218.

Solheim, W., 1984. The Nusantao hypothesis: the origin and spread of Austronesian speakers. Asian Perspectives 25 (1): 77-88.

Spriggs, M. 2011. Archaeology and the Austronesian expansion: where are we now? In Antiquity Vol. 85: 510-528

Spriggs, M. 1989. Dating the island Southeast Asian Neolithic: an attempt at chronometric hygiene and linguistic correlation. Antiquity 63: 587-613.,

Viet, N. and Oanh, N. 2002. Archaeology of death in Vietnam from Hoabinhian to Dongsonian. In. A. Karlstrom and A. Kallen (eds) Fishbones and Glittering Emblems: 81-88. Stockholm: Museum for Far Eastern Antiquities.

Zuraina Majid 1982. The West Mouth, Niah, in the Prehistory of Southeast Asia, Sarawak Museum Journal 31: 1-200.

Zuraina Majid. 2005. The Perak Man and other Prehistoric Skeletons of Malaysia. Penang: Universiti Sains Malaysia Pusat Penyelidikan Arkeologi Malaysia. 